\title{
Spatial Patterns of Macrozoobenthos Assemblages in a Sentinel Coastal Lagoon: Biodiversity and Environmental Drivers
}

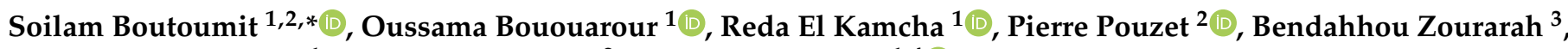 \\ Abdelaziz Benhoussa ${ }^{1}$, Mohamed Maanan ${ }^{2}$ and Hocein Bazairi ${ }^{1,4}$ \\ 1 BioBio Research Center, BioEcoGen Laboratory, Faculty of Sciences, Mohammed V University in Rabat, \\ 4 Avenue Ibn Battouta, Rabat 10106, Morocco; oussama.bououarour@um5r.ac.ma (O.B.); \\ redaelkamcha@gmail.com (R.E.K.); benhoussa@fsr.ac.ma (A.B.); hocein.bazairi@um5.ac.ma (H.B.) \\ 2 LETG UMR CNRS 6554, University of Nantes, CEDEX 3, 44312 Nantes, France; \\ pierre.pouzet@univ-nantes.fr (P.P.); mohamed.maanan@univ-nantes.fr (M.M.) \\ 3 Marine Geosciences and Soil Sciences Laboratory, Associated Unit URAC 45, Faculty of Sciences, \\ Chouaib Doukkali University, El Jadida 24000, Morocco; zourarah@gmail.com \\ 4 Institute of Life and Earth Sciences, Europa Point Campus, University of Gibraltar, \\ Gibraltar GX11 1AA, Gibraltar \\ * Correspondence: soilam_boutoumit@um5.ac.ma
}

\section{check for} updates

Citation: Boutoumit, S.; Bououarour, O.; El Kamcha, R.; Pouzet, P.;

Zourarah, B.; Benhoussa, A.; Maanan, M.; Bazairi, H. Spatial Patterns of

Macrozoobenthos Assemblages in a Sentinel Coastal Lagoon: Biodiversity and Environmental Drivers. J. Mar. Sci. Eng. 2021, 9, 461. https://doi. org/10.3390/jmse 9050461

Academic Editor: William

G. Ambrose

Received: 14 March 2021

Accepted: 21 April 2021

Published: 23 April 2021

Publisher's Note: MDPI stays neutral with regard to jurisdictional claims in published maps and institutional affiliations.

Copyright: (c) 2021 by the authors. Licensee MDPI, Basel, Switzerland. This article is an open access article distributed under the terms and conditions of the Creative Commons Attribution (CC BY) license (https:/ / creativecommons.org/licenses/by/ $4.0 /)$.
Abstract: This study presents an assessment of the diversity and spatial distribution of benthic macrofauna communities along the Moulay Bousselham lagoon and discusses the environmental factors contributing to observed patterns. In the autumn of 2018, 68 stations were sampled with three replicates per station in subtidal and intertidal areas. Environmental conditions showed that the range of water temperature was from $25.0^{\circ} \mathrm{C}$ to $12.3^{\circ} \mathrm{C}$, the salinity varied between 38.7 and 3.7, while the average of $\mathrm{pH}$ values fluctuated between 7.3 and 8.0. In vegetated habitats, biomass values of the seagrass Zostera noltei Hornemann ranged between $31.7 \mathrm{gDW} / \mathrm{m}^{2}$ and $170.2 \mathrm{gDW} / \mathrm{m}^{2}$ while the biomass of the seagrass Ruppia cirrhosa (Petagna) Grande between $54.2 \mathrm{gDW} / \mathrm{m}^{2}$ and $84.7 \mathrm{gDW} / \mathrm{m}^{2}$. Sediment analyses showed that the lagoon is mainly composed of sandy and silty sediments. We recorded 37,165 individuals of macrofauna distributed in 63 taxa belonging to 50 families, with a mean abundance value of $4582.8 \mathrm{ind} / \mathrm{m}^{2}$ and biomass average of $22.2 \mathrm{~g} / \mathrm{m}^{2}$. Distance-based linear modeling analysis (DISTLM) identified sediment characteristics, water parameters and habitat type (biomass of $Z$. noltei) as the major environmental drivers influencing macrozoobenthos patterns. Our results clearly revealed that the hydrographic regime (marine and terrestrial freshwater), sediment distribution and characteristics and the type of habitat (vegetated vs. unvegetated substrate) are the key factors determining the species composition and patterns of macrozoobenthos assemblages.

Keywords: Moulay Bousselham lagoon; benthic macrofauna; Semi Enclosed Coastal System; Atlantic Morocco

\section{Introduction}

Coastal lagoons are among the marine habitats with the highest biological productivity [1] and perform an important ecological function by providing forty-one varieties of goods and services [2]. However, coastal lagoons are semi-enclosed coastal systems (SECS) where environmental conditions are highly changeable due to their confined nature and their shallowness. SECS are especially vulnerable to the impacts of human activities resulting from mining, industry, tourism and urban development [3,4]. The geomorphology of these SECS renders them particularly vulnerable to global changes, such as sea-level rises, increased temperatures, storminess, droughts, floods and changes in sediment dynamics. They are "hotspots" of global change and vulnerability to environmental, economic and social pressures [5].

Coastal lagoons are sentinel systems that are highly vulnerable to the impacts of climate change [6]. They have natural conditions that play a key role in regulating water 
movement and nutrient accumulation between land, rivers and the ocean [7]. Sea level, temperature, precipitation and storms are expected to change significantly with global climate change and have a direct impact on coastal lagoons. These changes could modify the composition and diversity of natural communities, such as changes in community composition and diversity, sensitivity to eutrophication, loss of native species and their capacity to provide goods and services [8,9]. The conservation of coastal lagoons is therefore relevant for their ecological importance, as well as for the valuable ecosystem services (ES) they provide for human welfare.

Macrozoobenthos is a key component of the coastal ecosystems process, which substantially modifies the physical structure of the abiotic or biotic materials forming the habitat and thus directly or indirectly changes the availability of resources to other species [10]. They are important as food sources for organisms of the upper trophic levels [11]. Moreover, benthic macrofauna improves and preserves water quality through mineralization, and recycling of organic matters structures and oxygenates the bottom by reworking sediments, recycles nutrients, decomposes organic matter and linking primary production with higher trophic levels [12]. Hence, it is used as an indicator for the detection of types and levels of stress in environmental impact studies [13] and in environmental quality assessment of coastal systems [14].

The Moulay Bousselham lagoon is one of the most important coastal wetlands on the Moroccan Atlantic coast. It represents the most important Moroccan site for the migration and wintering of birds (exceeding $56 \%$ of the total number of wintering waders in Morocco); it relays migration between the European and African continents for many species of western Palearctic birds [15-17]. The importance of this Ramsar site is primarily due to the remarkable diversity of its habitats [15] and their associated flora and fauna. The lagoon of Moulay Bousselham is one of the Moroccan sites that has benefited the most from national and international conservation status: Ramsar Site, Biological Reserve, Game Reserve, Site of Biological and Ecological Interest (SIBE) and Area of Importance for the Conservation of Birds (ZICO).

Nevertheless, the close dependence of the local residents on the natural resources of the site calls into question its balance and threatens the sustainability of the availability of these resources. The intense development of human activities (urban pressure, overgrazing and overexploitation of water and plant resources) has reduced the surface area of the site's natural habitats and consequently its biological diversity [18]. In fact, the area of the latter currently occupies only about 3000 ha out of the 4500 to 5000 ha, representing their initial area when the site was listed as a Ramsar site in 1980 [15]. On the other hand, the misuse of fertilizers and phytosanitary products in adjacent agricultural areas and the discharge of sewage from the highway into the lagoon contribute to eutrophication and contamination of water and sediments (hydrocarbons, heavy metals) $[19,20]$.

The Moulay Bousselham lagoon is the most studied system on the Atlantic coast of Morocco for birds [21] and therefore is a good sentinel site to survey the global change effect, including climate change, on the African Atlantic and allows for comparison with other similar SECS on the European Atlantic coasts. Up until now, there is no extensive study of the benthic macrofauna and their spatial patterns in the Moulay Bousselham lagoon. Studies carried out by $[18,21-24]$, are all limited to a part of the ecosystem. Here, we attempt to contribute to filling this gap in our current knowledge with a basic study of the intertidal and subtidal macrofauna of this coastal lagoon. Our study, based on an extensive sampling, is the first to cover the whole area of the lagoon.

The aim of this study is to provide new insight into the biodiversity of the macrozoobenthos assemblages inhabiting the Moulay Bousselham lagoon, their composition, structure and spatial patterns. This study also aims to highlight the environmental drivers that govern the spatial distribution of benthic communities. 


\section{Materials and Methods}

\subsection{Study Area}

The Moulay Bousselham lagoon is the northernmost lagoon on the Moroccan Atlantic coast (Figure 1). The lagoon is located $125 \mathrm{~km}$ north of Rabat; it has an elliptical shape, with a maximum length of $9 \mathrm{~km}$, a maximum width of $5 \mathrm{~km}$ and an area of $35 \mathrm{~km}^{2}$. The communication of the lagoon with the Atlantic Ocean is done through a narrow, sinuous and relatively deep gully (up to $6 \mathrm{~m}$ ), which branches out in the direction of the lagoon by shallow subtidal channels, ensuring the circulation of water during the flood and ebb. The freshwater supply is provided by two rivers: Canal Nador in the south and Oued Drader in the northeast of the lagoon. The tidal part of the latter course divides the lagoon into two body-waters locally known as 'Merja': (i) The Merja Kahla, which is extended on $3 \mathrm{~km}$ on the north part of the lagoon, is very shallow, and its bottom is covered with a very dark mud; and (ii) the Merja Zerga, which represents the major part of the lagoon as it is extended over $27 \mathrm{~km}^{2}$ and appears blue due to its high depth at high tides [21]. The depth of the lagoon varies between 0 and $2 \mathrm{~m}$ depending on the tidal cycle and rainfall. During the annual cycle, the average salinity of the lagoon water fluctuates from 24.0 to 36.3 at high tide and from 8.0 to 32.5 at low tide [25].

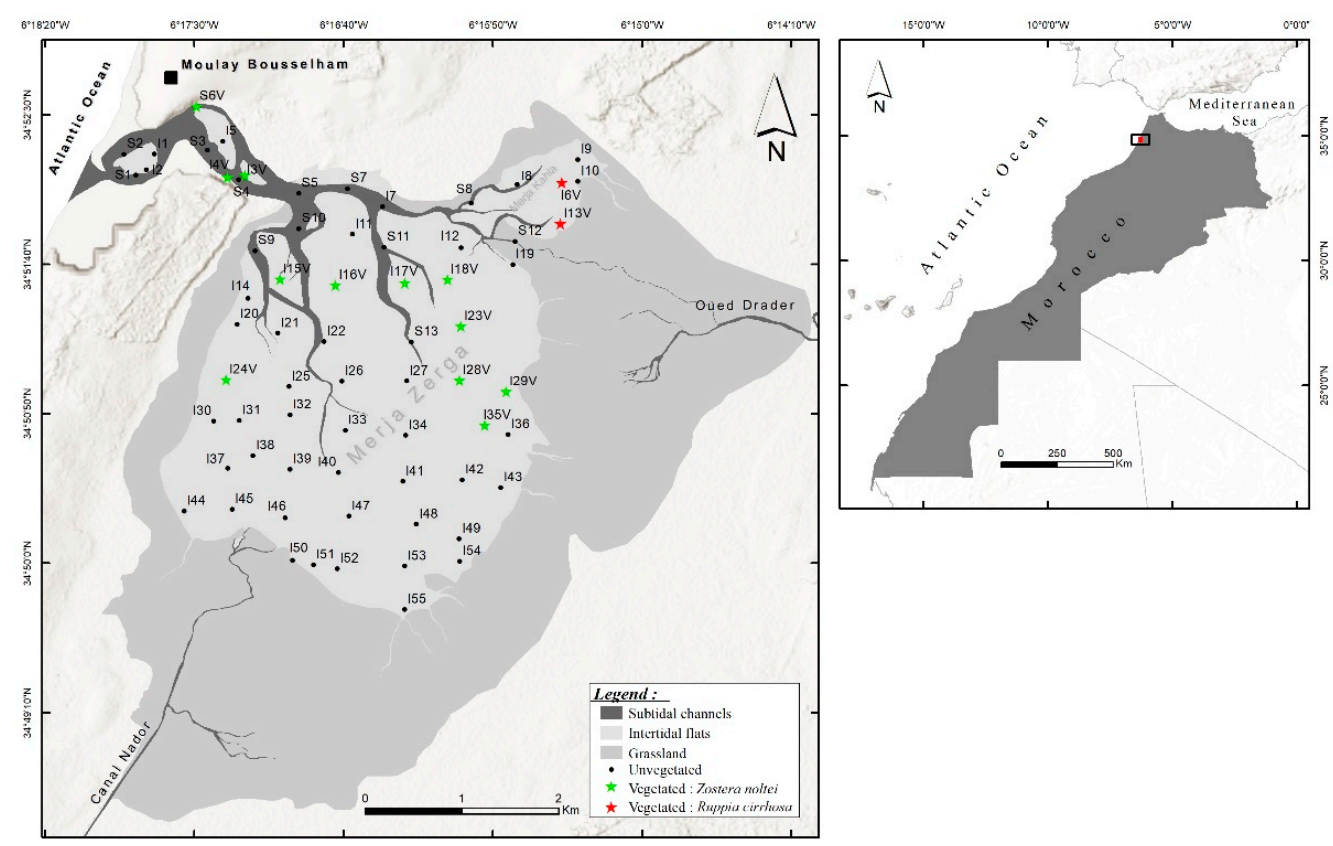

Figure 1. Map showing the location of the Moulay Bousselham lagoon and sampling stations. S: subtidal; I: intertidal; V: vegetated.

\subsection{Sample Collection and Environmental Analyses}

Grid sampling design encompasses the entire intertidal and subtidal areas of the Moulay Bousselham lagoon, with a combination of sample points taken at $500 \mathrm{~m}$ intervals. Sixty-eight stations (Figure 1) were sampled in the autumn of 2018 with three replicas per station. In subtidal areas, the samples were collected using a Van Veen grab, and each sample had a surface area of $0.1 \mathrm{~m}^{2}$. While in intertidal zone, samples were taken using a PVC corer with a diameter of $12.5 \mathrm{~cm}$, and each replica was a fusion of 10 cores, covering a total area of approximately $0.12 \mathrm{~m}^{2}$.

The samples were sieved in situ through a $1 \mathrm{~mm}$ mesh. The material retained on the mesh was fixed and preserved in seawater with formalin (4\%) and colored with Rose Bengal. In the laboratory, macroinvertebrates were sorted, identified and counted. Biomasses were obtained after calcination in the oven at $450{ }^{\circ} \mathrm{C}$ for $4 \mathrm{~h}$.

Physicochemical parameters (water temperature, salinity and $\mathrm{pH}$ ) were also measured in situ with a HANNA portable multiparameter. Each sample of the macrofauna was 
accompanied by an additional sediment sample to determine their precise granulometry, carbon content and total organic matter (TOM).

Grain size was measured using a laser particle size analyzer (Malvern Mastersizer 2000()) after preparing the sediments in a sodium hexametaphosphate solution [26]. The grain size distribution was then treated with the Gradistat@ Excel package [27]. Mean, sorting, skewness, kurtosis, decile statistics (including the median used to characterize the sediment type: d50) and clay/silt/sand composition were calculated to precise the textural group of each sample [28,29]. A LECO○ carbon analyzer estimated the carbon, $\mathrm{CO}_{2}$ and $\mathrm{CaCO}_{3}$ percentages after $1400{ }^{\circ} \mathrm{C}$ dioxygen burning and mineral decarbonizing with sulfuric acid solution [30], while the organic matter content was determined by estimating the total organic matter (TOM). The samples were oven dried (at $60^{\circ} \mathrm{C}$ for $48 \mathrm{~h}$ ) and ignited in an oven for $4 \mathrm{~h}$ at $500^{\circ} \mathrm{C}$. The percentage weight loss during the ignition step is reported as TOM [31]. When present, the biomasses of the seagrasses Zostera noltei Hornemann and Ruppia cirrhosa (Petagna) Grande were measured using a dry weight $\left(\mathrm{gDW} / \mathrm{m}^{2}\right)$. The seagrasses were isolated and rinsed with water and then dried in an oven at $60^{\circ} \mathrm{C}$ for $48 \mathrm{~h}$.

\subsection{Data Analysis}

The data matrix with macrofaunal abundance per station was transformed into square root, and then the Bray-Curtis similarity was calculated between stations. The similarity matrix was analyzed using agglomerative hierarchical clustering (AHC) to identify macrofaunal affinities. The environmental variables were transformed to $\log (X+1)$. Percentage similarity analysis (SIMPER) was used to identify the taxa that contributed most to disparities between each identified assemblage and to the dissimilarity among them.

DISTLM analysis (Distance-based linear modeling) was used to assess the contribution of environmental variables to the variability observed in the macrofaunal assemblages [32]. Results were visualized using the graphical representation of the ordination method of redundancy analysis (RDA). RDA is a constrained ordinate used to identify the linear combinations of predictor variables that explain the greatest variation in the species/abundance matrix, i.e., it shows the pattern of species/abundance (response) data as constrained by the predictor variables [33].

Spatial distribution and biodiversity were described by univariate analyses based on the following parameters: abundance ( $\mathrm{N}$, the number of individuals per $\left.\mathrm{m}^{2}\right)$, species richness (S), Shannon-Wiener diversity index $\left(\mathrm{H}^{\prime}\right)$ [34] and Pielou's evenness index ( $\left.\mathrm{J}^{\prime}\right)$ [35]. All these analyses were performed with PRIMER v6.0 software [36,37].

The $(\mathrm{S})\left(\log _{2} \mathrm{~S}\right)$ and $\left(\mathrm{H}^{\prime}\right)$ indices of the assemblages were plotted together on a twodimensional graphical representation in the Diversity Model (DIMO) considered as a synthetic tool [38].

\section{Results}

\subsection{Environmental Variables}

The spatial variation of environmental conditions is shown in Figure 2. The range of water temperature was from $12.3^{\circ} \mathrm{C}$ at station $\mathrm{I} 50$ to $25.0^{\circ} \mathrm{C}$ at station S1. The salinity varied among stations, with the maximum recorded at station S2 (38.7) and the minimum at the station $\mathrm{I} 50$ (3.7). The $\mathrm{pH}$ values fluctuated between 7.3 (station I9) and 8.0 (station I22). In stations with vegetated habitats (Figure 1), biomass values of Zostera noltei seagrass ranged between $31.7 \mathrm{gDW} / \mathrm{m}^{2}$ in station $\mathrm{I} 29 \mathrm{~V}$ and $170.2 \mathrm{gDW} / \mathrm{m}^{2}$ in station $\mathrm{I} 23 \mathrm{~V}$, while the biomass of Ruppia cirrhosa seagrass ranged between $54.2 \mathrm{gDW} / \mathrm{m}^{2}$ in $\mathrm{I} 6 \mathrm{~V}$ and $84.7 \mathrm{gDW} / \mathrm{m}^{2}$ in I13V.

Grain size parameters also vary depending on the location of each station (Figure 2). Stations S10, S3 and S4 are dominated by sands ( $>94 \%)$, with a median grain size (d50) higher than $350 \mu \mathrm{m}$ and consequently low mud values (around 3-5\%). S11, I1, S1, S12, S6V, I2, S5, S2, I46, S13 and S9 have more important silt proportion (around 10 to 20\%). As their d50 reaches high values $(>300 \mu \mathrm{m})$, their main sediment type is characterized as "muddy sands" to "sands", depending on their sand content. Fourteen other samples are more 
heterogeneous: S7, I41, I34, I5, I9, I11, S8, I22, I17V, I42, I30, I19, I28V and I3V (around 50\% and reaching $75 \%$ of dominating silts and sands); depending on their dominance, they are characterized as "silty sands" or "sandy silts". Their mud content reaches values from 25 to $75 \%$ in the order of the previous station list. The "sandy silts" textural category also includes a list of thirty stations studied: I40, I18V, I15V, I4V, I7, I32, I25, I20, I6V, I26, I48, I33 and I54 as silt variates between 70 and $80 \%$, and the d50 is inferior to $25 \mu \mathrm{m}$ ("medium" or "coarse silt" category). The clay percentage reaches $4.8 \%$ for the most clayey-rich station (I27), integrated into the lower grain-sized sediment samples where the 27 other stations are integrated. These stations have the lowest granulometry, with a median grain size of $7.3 \mu \mathrm{m}$ and the highest mud proportion (from 85 to $99 \%$ ).

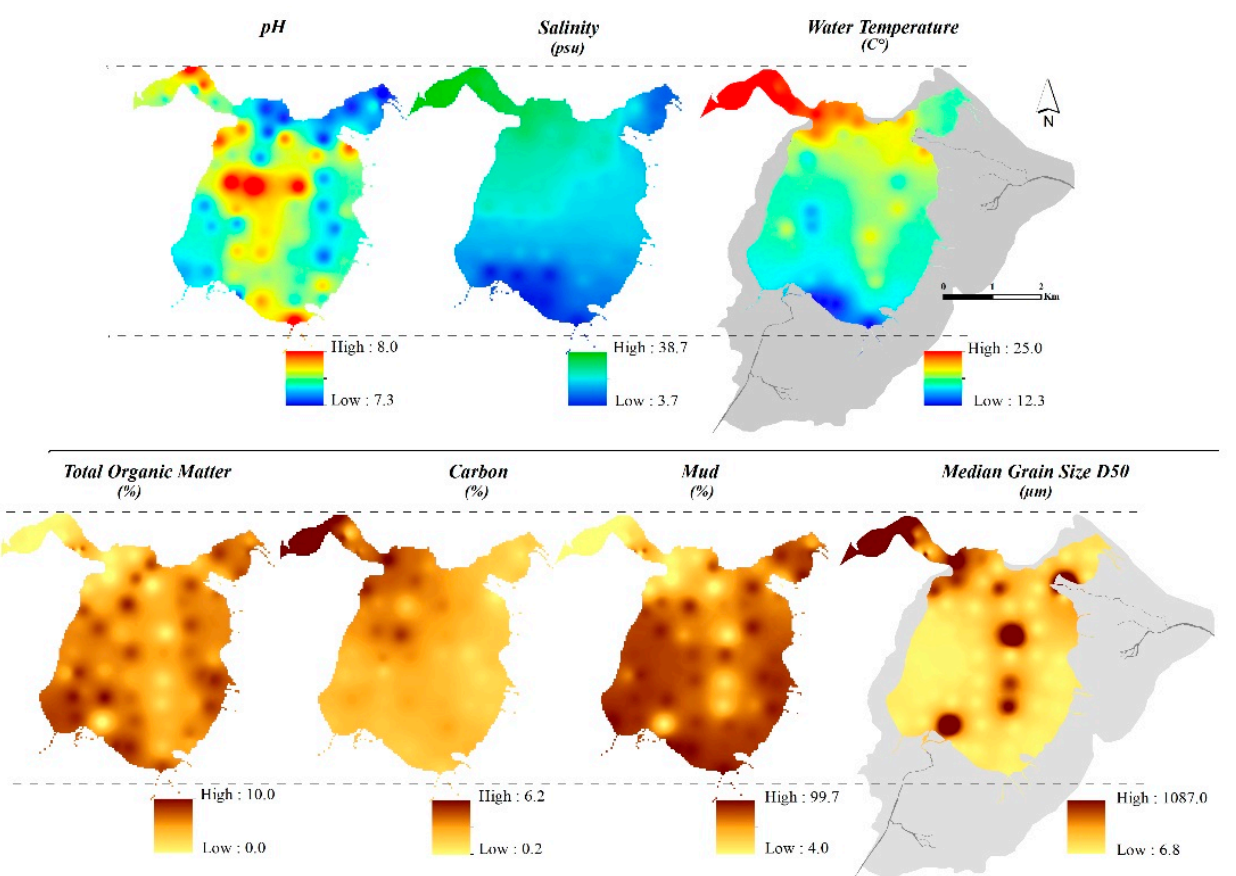

Figure 2. Maps showing the spatial distribution of environmental variables in the Moulay Bousselham lagoon.

Carbon content (carbon, $\mathrm{CO}_{2}$ and $\mathrm{CaCO}_{3}$ percentages) is higher in the "sand" and "silty sand" textural categories. These refer to the stations I2 (with the highest value of $6.2 \%), \mathrm{S} 2, \mathrm{~S} 1, \mathrm{I} 1, \mathrm{~S} 6 \mathrm{~V}, \mathrm{~S} 5, \mathrm{~S} 3, \mathrm{~S} 9, \mathrm{I} 22, \mathrm{~S} 4, \mathrm{I} 11, \mathrm{~S} 10$ and I21, located nearest to the channels and the inlet (Figure 2). These high values refer to the shells that remain observed in marine sands. In opposition, carbon values are lower $(<1.5 \%)$ in the muddy dominated samples (in most of the "mud" and "sandy mud" textural categories): I24V, I39, I31, I29, I27, I46, I50, I44, I8, I13V, I9, I16V, I30, I51, I52, I42, I43, I36, I32, I10, I55, I5, S12, I35V, I28V, I6V and I19 (with the lowest $0.2 \%$ value), where most of these sediments sampled are located far from the channels (Figure 2).

The total organic matter (TOM) ranged from $0.3 \%$ (S10) to $9.6 \%$ (I39). Higher values of TOM are detected far from the inlet and the channels because the decrease of water currents allows for the deposition of fine sediments together with particulate organic matter and detritus in muddy sediments (Figure 2). Consequently, stations I39, I37, I52, I16V, I51, I36, I45, I31, I8, I43, I44, I55, I7, I21, I35V and I26 shows higher TOM proportions (>8\%). In opposition, marine sands have low values of TOM (values $<2 \%$ for the S2, S7, I2, S12, S13, S1, S5, S6V, I1, S11, S3, S4, I46 and S10 stations). 


\subsection{Benthic Macrofauna}

Overall, 37,165 individuals of benthic macrofauna were collected and are distributed on 63 taxa including 50 families. Mollusca was the predominant phylum with 24 species belonging to 18 families. For Arthropoda, 20 species were counted with 19 families. The phylum Annelida was the third dominant group with 18 species belonging to 12 families. One family represented the phylum Nemertea.

The species richness (S) ranges between 3 and 35, respectively, at stations I2 and I7, while the abundance fluctuates between $66.7 \mathrm{ind} / \mathrm{m}^{2}$ (station I2) and $25625.0 \mathrm{ind} / \mathrm{m}^{2}$ (station I23V). The values of the diversity index $\left(\mathrm{H}^{\prime}\right)$ vary between 0.4 (station I1) and 2.5 (station I39). For the vast majority of stations, equitability index $\left(\mathrm{J}^{\prime}\right)$ values are high, indicating the equity of species dominance. The lowest biomass value was recorded at station I2 $\left(0.2 \mathrm{~g} / \mathrm{m}^{2}\right)$, while the highest value was recorded at station I17V $\left(92.5 \mathrm{~g} / \mathrm{m}^{2}\right)$ (Figure 3).

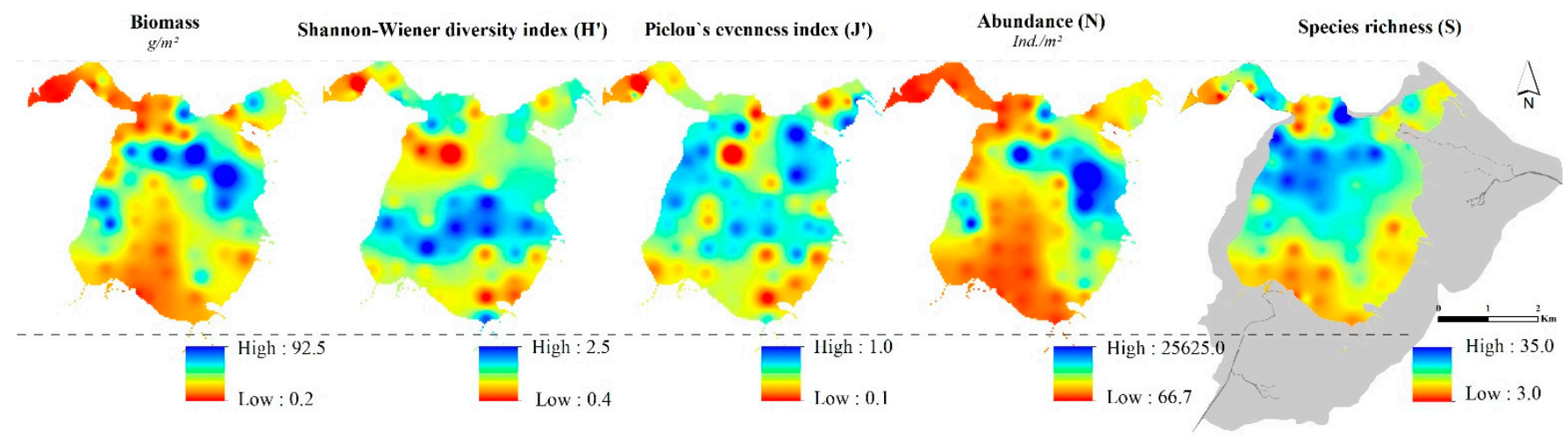

Figure 3. Interpolation of the spatial distribution of species richness $(\mathrm{S})$, abundance $(\mathrm{N})$, diversity index $\left(\mathrm{H}^{\prime}\right)$, equitability index $\left(\mathrm{J}^{\prime}\right)$ and the biomass in the Moulay Bousselham lagoon.

Peringia ulvae (Pennant, 1777), Capitella capitata (Fabricius, 1780), Lekanesphaera rugicauda (Leach, 1814), Heteromastus filiformis (Claparède, 1864), Scrobicularia plana (da Costa, 1778), Chironomidae, Melita palmata (Montagu, 1804), Pseudopolydora antennata (Claparède, 1869), Cyathura carinata (Krøyer, 1847) and Haminoea navicula (da Costa, 1778) were the most abundant and/or common species with an average abundance respectively of: 1251.0 ind $/ \mathrm{m}^{2}, 381.5$ ind $/ \mathrm{m}^{2}, 187.9$ ind $/ \mathrm{m}^{2}, 177.2$ ind $/ \mathrm{m}^{2}, 158.9$ ind $/ \mathrm{m}^{2}, 142.8 \mathrm{ind} / \mathrm{m}^{2}$, 115.5 ind $/ \mathrm{m}^{2}, 102.2$ ind $/ \mathrm{m}^{2}, 99.8$ ind $/ \mathrm{m}^{2}$ and 90.6 ind $/ \mathrm{m}^{2}$.

Cluster analysis, based on the abundance matrix of the 68 stations, indicates a high degree of spatial heterogeneity (Figures 4 and 5). The dendrogram showed a stratification of fourteen clusters: 8 multi-stations, 1 doubleton and 4 singletons. 


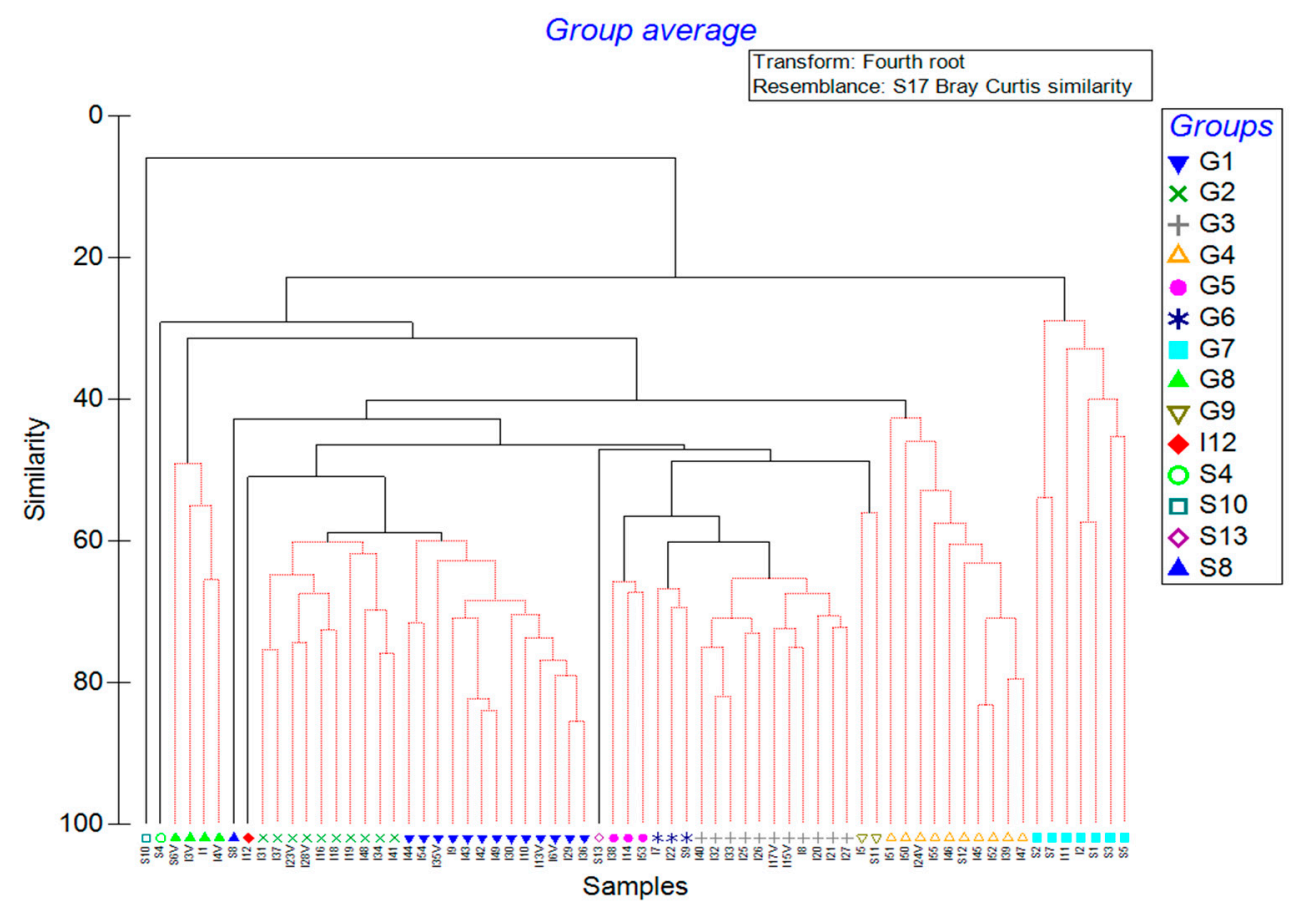

Figure 4. Cluster obtained from the ascending hierarchical classification (AHC) based on the similarity matrix of macrofauna.

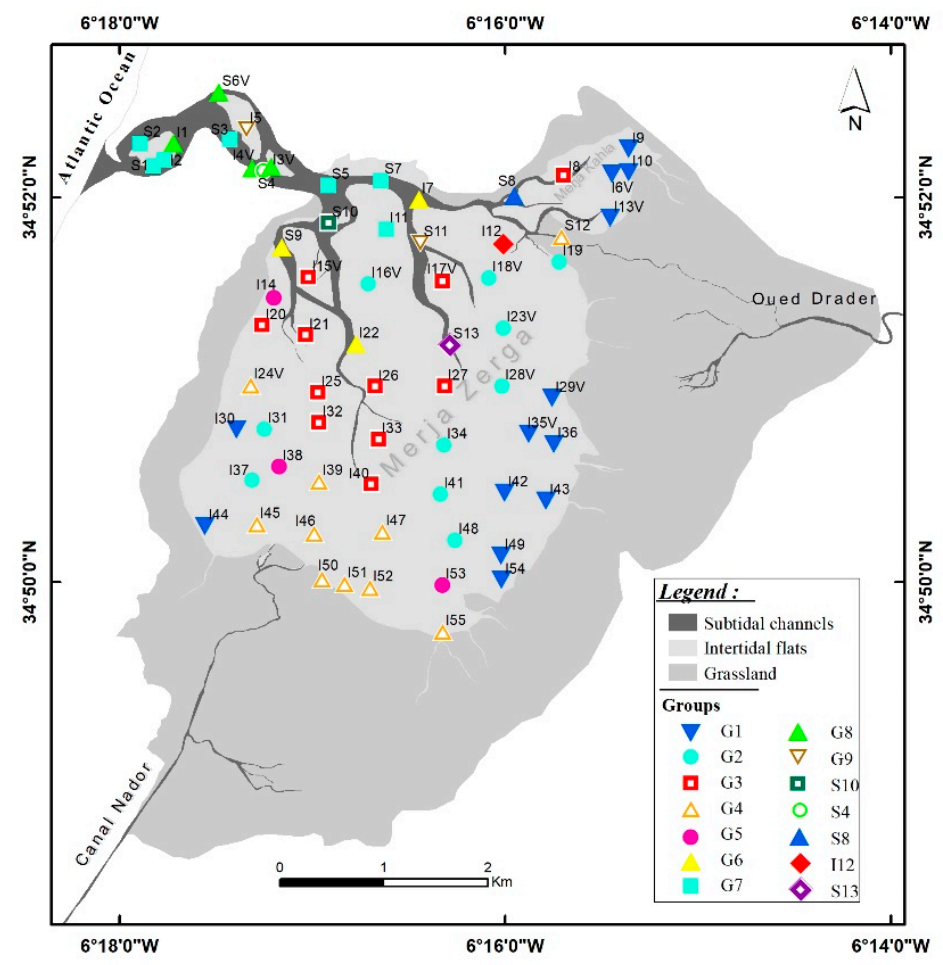

Figure 5. Map showing the spatial distribution of the groups of stations identified by cluster analysis based on the similarity matrix of macrofauna.

The characteristic species of each benthic assemblage have been identified by the SIMPER analysis (Table 1). Taxons that have largely contributed to the similarity of group G1 (67.36\%) were Peringia ulvae (22.80\%), Capitella capitata $(14.89 \%)$ and Chironomidae (12.58\%). The group G2 (63.59\%) is dominated by Peringia ulvae (16.73\%), Capitella capitata $(12.09 \%)$, Scrobicularia plana (8.66\%), Lekanesphaera rugicauda (6.97\%) and Cyathura carinata (6.27\%). Dominant species in the group G3 (67.94\%) were Scrobicularia plana $(10.34 \%)$, 
Cyathura carinata $(9.87 \%)$, Peringia ulvae (8.51\%), Streblospio shrubsolii (Buchanan, 1890) $(7.70 \%)$, Haminoea navicula $(7.64 \%)$ and Heteromastus filiformis $(7.56 \%)$. In the group G4 (54.97\%), the dominated taxa were Cyathura carinata (24.04\%), Peringia ulvae $(21.85 \%)$ and Scrobicularia plana (16.83\%). Group G5 (66.32\% of similarity) is characterized by the dominance of Peringia ulvae (17.83\%), Scrobicularia plana $(13.40 \%)$, Cyathura carinata $(12.33 \%)$ and Hediste diversicolor (O.F. Müller, 1776) (11.29\%). The characteristic species of the group G6 (67.73\% of similarity) were Heteromastus filiformis (9.41\%), Cyathura carinata (6.71\%), Capitella capitata (5.85\%), Scrobicularia plana (5.85\%), Streblospio shrubsolii (5.30\%), Haminoea navicula (5.06\%), Peringia ulvae (4.61\%), Glycera tridactyla (Schmarda, 1861) (4.60\%) and Cerastoderma edule (Linnaeus, 1758) (4.49\%). Contributing species for the group G7 (35.16\%) were Peringia ulvae (40.33\%) and Lekanesphaera rugicauda (26.68\%). Regarding the group G8 (53.85\%), the dominated taxa were Heteromastus filiformis (13.76\%), Abra tenuis (Montagu, 1803) (12.65\%), Abra alba (W. Wood, 1802) (10.94\%), Peringia ulvae $(10.70 \%)$ and Nephtys hombergii (Savigny in Lamarck, 1818) (7.86\%). While Peringia ulvae (16.56\%), Glycera tridactyla (9.39\%), Spio filicornis (Müller, 1776) (8.49\%) Tritia pfeifferi (Philippi, 1844) (8.49\%) and Cerastoderma edule (7.14\%) were the dominant taxon for G9 (56.08\%). Stations S10, S4, $\mathrm{S} 8, \mathrm{I} 12$, and S13 were isolated to defined groups with a single station.

Table 1. SIMPER results showing the average similarity between benthic assemblages identified by Cluster analysis and the contribution of characteristic species of each benthic assemblage.

\begin{tabular}{|c|c|c|c|c|c|c|c|c|c|}
\hline & G1 & G2 & G3 & G4 & G5 & G6 & G7 & G8 & G9 \\
\hline & $67.36 \%$ & $63.59 \%$ & $67.94 \%$ & $54.97 \%$ & $66.32 \%$ & $67.73 \%$ & $35.16 \%$ & $53.85 \%$ & $56.08 \%$ \\
\hline Species Contribution \% & - & - & - & - & - & - & - & - & - \\
\hline Abra alba & - & - & - & - & - & - & - & 10.94 & - \\
\hline Abra tenuis & - & & - & - & - & - & - & 12.65 & - \\
\hline Capitella capitata & 14.89 & 12.09 & - & - & - & 5.85 & - & - & - \\
\hline Cerastoderma edule & - & - & - & - & - & 4.49 & - & - & 7.14 \\
\hline Chironomidae larvae & 12.58 & - & - & - & - & - & - & - & - \\
\hline Cyathura carinata & - & 6.27 & 9.87 & 24.04 & 12.33 & 6.71 & - & - & - \\
\hline Glycera tridactyla & - & - & - & - & - & 4.60 & - & - & 9.39 \\
\hline Haminoea navicula & - & - & 7.64 & - & - & 5.06 & - & - & - \\
\hline Hediste diversicolor & - & - & - & - & 11.29 & - & - & - & - \\
\hline Heteromastus filiformis & & - & 7.56 & - & - & 9.41 & - & 13.76 & - \\
\hline Lekanesphaera rugicauda & - & 6.97 & - & - & - & - & 26.68 & - & - \\
\hline Nephtys hombergii & - & - & - & - & - & - & - & 7.86 & - \\
\hline Peringia ulvae & 22.80 & 16.73 & 8.51 & 21.85 & 17.83 & 4.61 & 40.33 & 10.70 & 16.56 \\
\hline Scrobicularia plana & - & 8.66 & 10.34 & 16.83 & 13.40 & 5.85 & - & - & - \\
\hline Spio filicornis & - & - & - & - & - & - & - & - & 8.49 \\
\hline Streblospio shrubsolii & - & - & 7.70 & - & - & 5.30 & - & - & - \\
\hline Tritia pfeifferi & - & - & - & - & - & - & - & - & 8.49 \\
\hline
\end{tabular}

The DIMO model distinctly separated the community groups and displayed a type 4 dynamic (non-constant type), where all three parameters $\left(\mathrm{S}, \mathrm{H}^{\prime}\right.$ and $\mathrm{J}^{\prime}$ ) changed (Figure 6). According to the DIMO model, the stations located in the muddiest areas (near the Nador Canal), some stations in the subtidal zone and others near the sea are the least diversified and structured, while vegetated habitats and surrounding areas are the most diversified and the well-structured. 


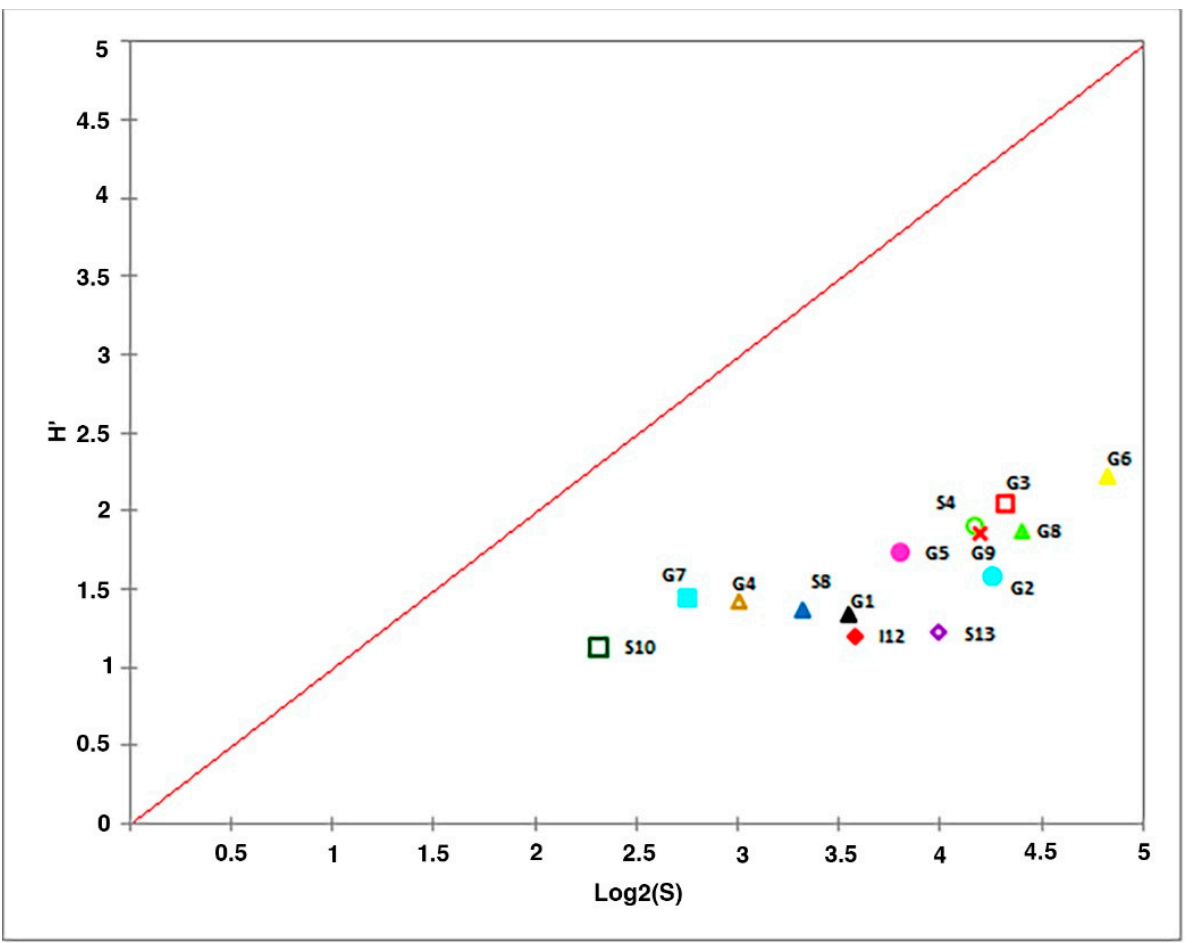

Figure 6. Simultaneous representation of species richness $\log _{2}(S)$, Shannon-Wiener index $\left(\mathrm{H}^{\prime}\right)$ of macrobenthos assemblages in the Moulay Bousselham lagoon using the DIMO model.

\subsection{Relationships between Macrobenthos and Environmental Conditions}

Results of the non-parametric multiple regression analysis (DISTLM) between community composition and environmental variables showed significant correlations with nine variables (Adjusted $\mathrm{R}^{2}=0.41 ; p<0.01$ ). These corresponded to the sediment characteristics (mud content, median grain-size, TOM (\%), carbon $\%, \mathrm{CaCO}_{3} \%$, and $\mathrm{CO}_{2} \%$ ), water characteristics $\left(\mathrm{T}^{\circ}, \mathrm{pH}\right.$, salinity) and habitat type (biomass of Zostera noltei) (Table 2).

Table 2. Results of DISTLM analyses showing relationships between environmental predictor variables and macrofauna community structure.

\begin{tabular}{ccccc}
\hline Variable & Pseudo-F & $p$-Value & Proportion & $\begin{array}{c}\text { Cumulative } \\
\text { Proportion }\end{array}$ \\
\hline Carbon $(\%)$ & 10.1160 & 0.0001 & 0.1329 & 0.1329 \\
Mud $(\%)$ & 4.1626 & 0.0001 & 0.0521 & 0.1850 \\
Water Temperature $\left({ }^{\circ} \mathrm{C}\right)$ & 3.9751 & 0.0002 & 0.0476 & 0.2327 \\
Z. noltei Biomass (gDW $\left./ \mathrm{m}^{2}\right)$ & 3.1734 & 0.0007 & 0.0369 & 0.2695 \\
pH & 2.8565 & 0.0016 & 0.0321 & 0.3017 \\
Salinity (PSU) & 2.5107 & 0.0080 & 0.0276 & 0.3293 \\
$\mathrm{CO}_{2}(\%)$ & 1.9516 & 0.0435 & 0.0211 & 0.3504 \\
$\mathrm{CaCO}_{3}(\%)$ & 3.0121 & 0.0004 & 0.0315 & 0.3819 \\
Median Grain-size $(\mu \mathrm{m})$ & 1.6806 & 0.0693 & 0.0174 & 0.3994 \\
Total Organic Matter $(\%)$ & 1.0395 & 0.4134 & 0.0107 & 0.4101 \\
\hline
\end{tabular}

Figure 7 shows the RDA ordination obtained using DISTLM. The pattern indicates that there are at least two trends in the macrofaunal community structure that can be modeled by these environmental drivers. The first clusters, which include stations located near/or in subtidal zones (G6, G7, G8, S4, S10), are driven by salinity, $\mathrm{pH}$, median grain size and carbon content in the sediment (percentage of: carbon, $\mathrm{CO}_{2}$ and $\mathrm{CaCO}_{3}$ ). The second trend highlights the variability between sites in the central and peripheral areas of the lagoon. These variations are related to differences in the percentage of TOM and mud in the sediment, water temperature, salinity and the presence of $Z$. noltei. The first 
axis explained $39.8 \%$ out of the fitted and $16.3 \%$ out of the total variation, while the second accounts for $26.2 \%$ of the fitted and $10.7 \%$ of the total variation. In total, the first two RDA axes explain $66 \%$ of the adjusted change, and this accounts for about $27 \%$ of the total change in the multivariate community data. The full RDA axis explains $100 \%$ of the adjusted variation and $41.02 \%$ of the total variation.

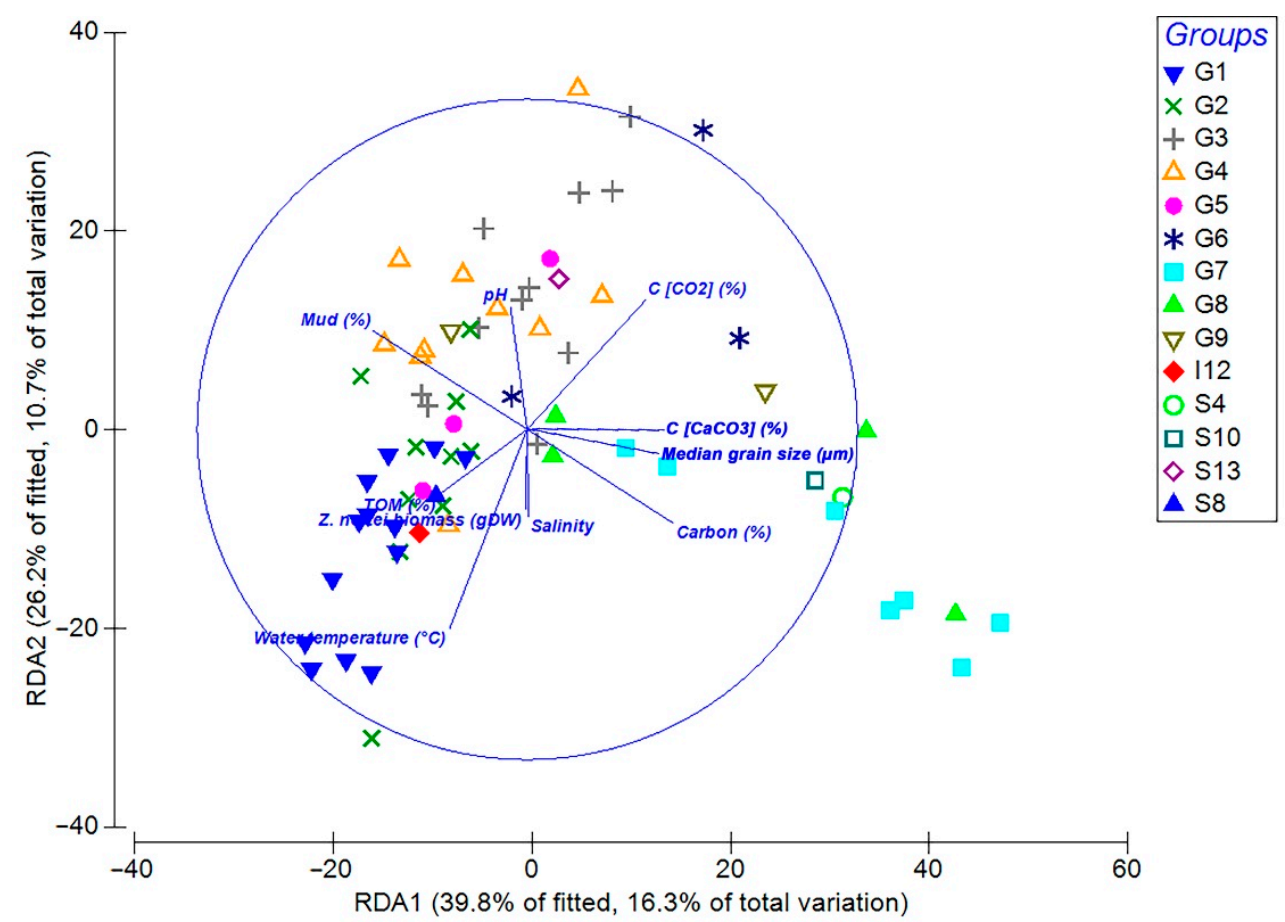

Figure 7. Two-dimensional redundancy analysis (RDA) ordination representing the model of spatial variation in macrozoobenthos community structure related to the predictor variables selected through the best linear models based on distance (DISTLM).

\section{Discussion}

Large spatial scale studies are crucial to better manage habitats and resources, particularly for the development of the relatively new ecosystem approach [39-42]. The relationships between macrobenthos and natural environmental drivers can thus be used to describe habitats, defined as the physical and chemical environment in which a species or community lives, and to provide a baseline for the detection of spatial and temporal changes [43-45]. In this context, our study, which covers the entire lagoon, gives an overview on the spatial patterns of the benthic macrofauna of the Moulay Bousselham lagoon in relation to environmental drivers.

\subsection{Environmental Variables}

In this study, not all water parameters varied as gradients between upstream and downstream areas. Only salinity and temperature clearly decreased with gradients upstream in conformity with the findings of $[21,46]$. Both salinity and temperature gradients resulted from the ocean-continent gradient related to the position of stations across the lagoon and the sampling time.

The salinity of coastal lagoons can vary from freshwater to hypersaline according to local climatic conditions and the degree of hydrological connectivity [47]. However, within a single lagoon system, there may be three salinity zones whose spatial extent varies depending on seasonal conditions. These are relatively fresh water near the mouths of influent rivers, brackish water in the central part of a lagoon, and marine salinities at the entrance channel (s). 
The Moulay Bousselham lagoon is mainly composed of sandy and silty sediments, and no gravel has been detected in each sample measured. The median grain size shows high variations, from fine silts to coarse sands. The main part of the lagoon is composed of poorly sorted sediments according to the Folk and Ward classification, with a mean sorting index of 3.9 estimated from the 68 samples. The sandy dominated stations revealed refer to sediments sampled downstream or in the channels, where higher grain-sized sediments are transported [28], while the lower grain-sized sediments with high mud content identified refer to sediments present in the upstream sections of the lagoon far. They are stations located away from the channels and where morphogenic conditions decrease [48]. Hydrodynamic energy affects sedimentation and resuspension of sediment particles [49,50], as well as organic enrichment of sediments [51,52]. Thus, higher currents and turbulence inhibit the deposition of organic matter and produce the deposition of coarse sediments $[49,53]$, whereas muddy sediments occur in calmer hydrodynamic conditions.

In opposition to the grain size parameters, carbon content presents lower variation, and only low carbon percentages have been recorded by LECO@ for the 68 stations studied. Higher carbon values in stations located nearest channels can be linked to the marine influence providing shell remains in the sands content, whereas the low values (in central and peripheral areas) can be influenced by the continental inputs coming from the watershed and bringing organic matter remains from vegetated areas [29]. The high level of TOM in the center and periphery of the lagoon can be attributed to the presence of fine particles entrapped by the structure of seagrass leaves and the abundance of fragments of dead seagrass encrusted in the sediment [54]. With higher water currents, TOM values are lower near the channels.

\subsection{Benthic Macrofauna}

In the 68 sampled stations, 63 taxa belonging to 50 families were identified. The soft-bottom macrofauna of the Moulay Bousselham lagoon was mainly characterized by the dominance of Mollusca (38.09\%), followed by Arthropoda (31.75\%), Annelida (28.57\%) and Nemertea (1.59\%). These results contrast both with previous studies carried out on the lagoon $[22,46,55,56]$, which noted the dominance of mollusks, polychaetes and crustaceans, and with the conclusions of [21], who noted the predominance of crustaceans, followed by polychaetes and mollusks. These results may be related to differences in sampling methods and designs.

Compared with previous studies, the number of species was higher than observed by [22]: 45, [23]: 54, [46]: 46 and lower than that obtained by [21]:173 taxa. In comparison with other lagoon systems, the species richness shows higher values than the lagoons of Sidi Moussa [55,57,58], Oualidia [59-61], Khnifiss [60,62], Ghar El-Melh [63], Mellah [64], Cabras [65,66], Celestun [67], Epe [68] and Lesina [69]. However, the species number was still lower than that Oualidia [54], Nador [70], Ria Formosa [71], Venice [72], Lagos [73], Bay of Muggia [74], Marano and Grado lagoon [75] and similar to those observed in Sacca di Goro lagoon [76].

On the other hand, the macrobenthic faunal densities observed in this study (4582.8 ind $/ \mathrm{m}^{2}$ ) were higher than those reported by [77] (3106.0 ind $\left./ \mathrm{m}^{2}\right)$ and lower to those observed by [46] (5763.0 ind $\left./ \mathrm{m}^{2}\right)$. The maximum biomass value reported in our study $\left(92.5 \mathrm{~g} / \mathrm{m}^{2}\right)$ is higher than that reported by [46]. The highest values were recorded in the vegetated habitats, while the mean value of the biomass $\left(22.2 \mathrm{~g} / \mathrm{m}^{2}\right)$ is similar to that reported by [78] $\left(22.0 \mathrm{~g} / \mathrm{m}^{2}\right)$ and very close to the results of [46] $\left(20.0 \mathrm{~g} / \mathrm{m}^{2}\right)$. Comparisons with these previous studies reveal that the benthic assemblages of the Moulay Bousselham lagoon are relatively stable, indicating a certain durability. Abundance and biomass were clearly lower compared with several other coastal systems: Venice lagoon [72], Prévost lagoon [79], Arcachon bay [80] and the Somme bay [81], but they were higher than those recorded in Boughrara lagoon [82] and Celestun lagoon [67]. 


\subsection{Spatial Patterns and Environmental Drivers}

The spatial pattern of the benthic communities in the lagoon follows a downstreamupstream gradient, essentially due to environmental factors including sediment characteristics, water parameters and the type of habitat (seagrass beds). The particular combination of those factors generates a macrofaunal structure characterized by 14 assemblages can be clearly seen in the cluster analysis. Assemblages are identified from downstream to upstream and from the center to the peripheral areas. According to cluster analysis, these assemblages showed a clear distinction between the part close to the sea communication (similarity not exceeding 30\%) and the parts inside the lagoon (similarity around $60 \%$ ). Our results also showed the association of stations located in the subtidal with others in the intertidal areas in the identified clusters (G6, G7 and G8). In contrast to the results obtained in the Moulay Bousselham lagoon by [46] and in the Oualidia lagoon by [61], our assemblages do not show a clear dominance of one or two species.

Most of the benthic species inventoried in the Moulay Bousselham lagoon had a wide spatial pattern and were not limited to a single habitat. Such a pattern corresponds better to the concept of a continuum of communities across an environmental gradient [83] than to the concept of discrete communities as distinct assemblages of species defined by [84]. The biological continuum and the absence of ecotonal zones seem to be characteristic of estuaries in particular and semi-enclosed coastal ecosystems [85]. Indeed, this pattern has been found in different estuaries in Morocco [86-88], France [89], Portugal [90,91] and Spain [92,93]. The explanation for this finding is probably the high tolerance of the macrozoobenthos species inhabiting such ecosystems. These patterns could also be related to the fact that environmental gradients are not so strong in the Moulay Bousselham lagoon, with the exception of salinity, and that the lagoon lacks large hydrodynamic variations, which commonly have a significant impact on the spatial distribution of benthic communities [94,95]. Analysis of macrobenthic assemblages indicates that the spatial distributions of the 63 taxa found along the subtidal and the intertidal stations of the Moulay Bousselham lagoon showed a relatively high correlation with environmental drivers and can be best explained by a combination of tex natural abiotic variables. DISTLM highlights sediment characteristics (mud content, median grain-size, $\mathrm{TOM} \%$, carbon $\%, \mathrm{CaCO}_{3} \%$, and $\mathrm{CO}_{2} \%$ ), water parameters (salinity, $\mathrm{T}^{\circ}, \mathrm{pH}$ ) and habitat type (biomass of Zostera noltei). There is a gradient from west to east, and the most important stations in terms of specific richness and/or density are those located in the central and peripheral mudflat areas, which are characterized by the presence of a seagrass bed, or located near vegetated areas (Zostera noltei, Ruppia cirrosa, Algae). Past works have shown that the spatial pattern of the benthic communities at Moulay Bousselham lagoon follows an upstream-downstream gradient and demonstrated the primordial role of environmental drivers (sediment grainsize, organic matter, hydrodynamics parameters and the presence of seagrass) on this distribution [21,46].

For macrobenthic invertebrates, such patterns are eventually the result of a complex interaction of a number of processes occurring in both the water column and the sedimentary compartment. Coastal lagoons are complex systems with a high degree of physical and biological variability.

The biodiversity of these ecosystems is commonly thought to be spatially distributed along the vertical and horizontal gradients of salinity, temperature, sediment characteristics (particle size, mud and/or organic matter enrichment) [96-98]. This spatial structure results from the environmental tolerances of organisms to stresses within these variable systems (water mass dynamics, physiological stress and biotic interactions) [99,100].

The presence of vegetation creates conditions for the formation of stable and complex habitats, thus promoting the installation of dense and diversified benthic communities [101,102]. The composition of the fauna is also driven by sediment, which is known to be a determinant of macrobenthic composition and plays an important role at different stages of the life cycle (settlement, tube building, burying and feeding) of soft-bottomed benthic organisms [103,104]. Our analyses have also highlighted salinity as a key factor, a parameter that has usually 
been considered essential to explain gradients in lagoon density, biomass, richness or diversity $[105,106]$ and as one of the main drivers of similarities and differences in lagoon assemblages [107-110].

Lagoons, however, are characterized by large seasonal, often unpredictable, variation in physical and chemical variables $[111,112]$. This may act as a driving force regulating the macrozoobenthic assemblages from season to season. At Moulay Bousselham lagoon, previous studies showed that benthic population density and species richness revealed seasonal variation with maxima in the autumn [21]. In the present study, the spatial patterns and associated key environmental drivers were evidenced from sampling performed during autumn where benthic macrofauna are the most diverse. Nevertheless, future studies should consider sampling over different seasons to better trace the physical and biotic factors regulating spatial and seasonal changes in the benthic assemblages of this temperate lagoon.

\section{Conclusions}

In conclusion, this study updates the composition of soft-bottom macrofaunal assemblages in the Moulay Bousselham lagoon and provides the first extensive examination of their spatial distribution.

Our results clearly revealed that the hydrographic regime (marine and terrestrial freshwater), the sediment distribution and characteristics, and the type of habitat (vegetated area) are the key factors determining the species composition and patterns of macrozoobenthos assemblages.

Author Contributions: Conceptualization, S.B., O.B. and R.E.K.; methodology, S.B., H.B. and M.M.; software, S.B., R.E.K. and P.P.; formal analysis, S.B.; O.B. and P.P.; investigation, S.B., O.B., R.E.K. and P.P.; resources, H.B., M.M., A.B. and B.Z.; data curation, S.B., H.B. and M.M.; writing-original draft preparation, S.B.; writing-review and editing, S.B., H.B., M.M., A.B. and B.Z.; supervision, H.B. and M.M.; funding acquisition, H.B., M.M., A.B. and B.Z. All authors have read and agreed to the published version of the manuscript.

Funding: This research was partially funded by BioEcoGen Laboratory, Faculty of Sciences, Mohammed V University in Rabat and UMR 6554 LETG, Nantes, France. The APC was funded by UMR 6554 LETG, Nantes, France.

Institutional Review Board Statement: Not applicable.

Informed Consent Statement: Not applicable.

Data Availability Statement: Data are contained within the article.

Conflicts of Interest: The authors declare no conflict of interest.

\section{References}

1. Alongi, D.M. Coastal Ecosystem Processes; CRC Press: Boca Raton, FL, USA, 1998.

2. Newton, A.; Brito, A.C.; Icely, J.D.; Delorez, V.; Clara, I.; Angus, S.; Schernewski, G.; Inácio, M.; Lillebø, A.I.; Sousa, A.I.; et al. Assessing, quantifying and valuing the ecosystem services of coastal lagoons. J. Nat. Conserv. 2018, 44, 50-65. [CrossRef]

3. Courrat, A.; Lobry, J.; Nicolas, D.; Amara, R.; Lepage, M.; Girardin, M.; Le Pape, O. Anthropogenic disturbances on nursery function of estuarine areas for marine fish species. Estuar. Coast. Shelf Sci. 2009, 81, 179-190. [CrossRef]

4. Ruiz-Fernández, A.C.; Maanan, M.; Sanchez-Cabeza, J.A.; Pérez Bernal, L.H.; López Mendoza, P.; Limoges, A. Chronology of recent sedimentation and geochemical characteristics of sediments in Alvarado Lagoon, Veracruz (southwestern Gulf of Mexico). Cienc. Mar. 2014, 40, 291-303. [CrossRef]

5. Newton, A.; Carruthers, T.J.B.; Icely, J. The coastal syndromes and hotspots on the coast. Estuar. Coast. Shelf Sci. 2012, 96, $39-47$. [CrossRef]

6. Eisenreich, S.J. Climate Change and the European Water Dimension; EU Report No. 21553; Joint Research Centre, European Commission: Ispra, Italy, 2005.

7. Brito, A.C.; Newton, A.; Tett, P.; Fernandes, T.F. Sediment and water nutrients and microalgae in a coastal shallow lagoon, Ria Formosa (Portugal): Implications for the water framework directive. J. Environ. Monit. 2010, 12, 318-328. [CrossRef] [PubMed]

8. Cossarini, G.; Libralato, S.; Salon, S.; Gao, X.; Giorgi, F.; Solidoro, C. Downscaling experiment for the Venice lagoon. II. Effects of changes in precipitation on biogeochemical properties. Clim. Res. 2008, 38, 43-59. [CrossRef] 
9. Melaku Canu, D.; Campostrini, P.; Dalla Riva, S.; Pastre, R.; Pizzo, L.; Rossetto, L.; Solidoro, C. Addessing sustainability of clam farming in the Venice Lagoon. Ecol. Soc. 2011, 16, 26. [CrossRef]

10. Lu, L. The relationship between soft bottom microbenthic communities and environmental variables in Singaporean waters. Mar. Pollut. Bull. 2005, 51, 1034-1040. [CrossRef] [PubMed]

11. Dauer, D.M. Biological criteria, environmental health, and estuarine macrobenthic community structure. Mar. Pollut. Bull. 1993, 26, 249-257. [CrossRef]

12. Sarker, J.M.; Patwary, S.A.M.; Borhan-Uddin, A.M.M.; Monjurul, H.M.; Tanmay, M.H.; Kanungo, I.; Parvej, M.R. Macrobenthic Community Structure-An Approach to Assess Coastal Water Pollution in Bangladesh. J. Fish. Aquac. 2016, 7, 1. [CrossRef]

13. Warwick, R.M. Environmental impact studies on marine communities: Pragmatical considerations. Aust. J. Ecol. 1993, 18, 63-80. [CrossRef]

14. Ponti, M.; Abbiati, M. Quality assessment of transitional waters using a benthic biotic index: The case study of the Pialassa Baiona (northern Adriatic Sea). Aquat. Conserv. 2004, 14, 31-41. [CrossRef]

15. Qninba, A. Les Limicoles (Aves, Charadrii) du Maroc: Synthèse sur L'hivernage à L'échelle Nationale et Etude Phénologique Dans le Site Ramsar de Merja Zerga. Ph.D. Thesis, Université Mohammed V, Rabat, Morocco, 1999.

16. Benhoussa, A. Caractérisation des Habitats et Microdistribution de L'avifaune de la Zone Humide de Merja Zerga (Maroc). Ph.D. Thesis, Université Mohammed V, Rabat, Morocco, 2000.

17. Thévenot, M.; Vernon, J.D.R.; Bergier, P. The Birds of Morocco; British Ornithologist Union Checklist: Hay-On-Wye, UK, 2003; Volume 20, p. 594.

18. Touhami, F. Caractérisation des Peuplements Benthiques des Habitats Intertidaux de Merja Zerga et Leur Utilisation par les Limicoles Hivernants. Ph.D. Thesis, Université Mohammed V, Rabat, Morocco, 2018.

19. Alaoui, M.A.; Choura, M.; Maanan, M.; Zourarah, B.; Robin, M.; Freitas, M.; Andrade, C.; Khalid, M.; Carruesco, C. Metal fluxes to the sediments of the Moulay Bousselham lagoon, Morocco. Environ. Earth Sci. 2010, 61, 275-286. [CrossRef]

20. Maanan, M.; Landesman, C.; Zourarah, B.; Fattal, P.; Sahabi, M. Evaluation of the anthropogenic influx of metal and metalloid contaminants into the Moulay Bousselham lagoon, Morocco, using chemometric methods coupled to geographical information systems. Environ. Sci. Pollut. Res. Int. 2013, 20, 4729-4741. [CrossRef] [PubMed]

21. Bazairi, H. La Faune Macrobenthique de la Lagune de Moulay Bousselham: Structure et Successions Spatio-Temporelles. Ph.D. Thesis, Université Mohammed V, Rabat, Morocco, 1999.

22. Lacoste, M. Contribution à L'étude Ecologique de la Lagune de Moulay Boussalham (Maroc). Ph.D. Thesis, Université Paul Sabatier, Toulouse, France, 1984.

23. Ait Mlik, K. Contribution à L'étude de L'évolution à Long Terme des Structures Benthiques de la Lagune de Merja Zerga. Master's Thesis, Université Hassan II, Casablanca, Morocco, 2009.

24. Bououarour, O. La Macrofaune Benthiques Des Herbiers de Zostera Noltii de la Lagune de Moulay Bousselham (Merja Zerga): Structure Des Communautés et état de la Qualité Ecologique. Master's Thesis, Université Mohammaed V, Rabat, Morocco, 2013.

25. Labbardi, H.; Ettahiri, O.; Lazar, S.; Massik, Z.; El Antri, S. Etude de la variation spatio-temporelle des paramètres physicochimiques caractérisant la qualité des eaux d'une lagune cotière et ses zonations écologiques: Cas de Moulay Bousselham, Maroc. Comptes Rendus Géosci. 2005, 337, 505-514. [CrossRef]

26. Gee, G.W.; Or, D. 2.4 Particle-Size Analysis; Dane, J.H., Topp, C.G., Eds.; SSSA Book Series; Soil Science Society of America: San Diego, CA, USA, 2002; pp. 255-293. [CrossRef]

27. Blott, S.J.; Pye, K. GRADISTAT: A grain size distribution and statistics package for the analysis of unconsolidated sediments. Earth Surf. Process. Landf. 2001, 26, 1237-1248. [CrossRef]

28. Pouzet, P.; Maanan, M.; Schmidt, S.; Athimon, E.; Robin, M. Correlating three centuries of historical and geological data for the marine deposit reconstruction of two depositional environments of the French Atlantic coast. Mar. Geol. 2019, 407, 181-191. [CrossRef]

29. Pouzet, P.; Maanan, M. Temporal approaches of historical extreme storm events based on sedimentological archives. J. Afr. Earth Sci. 2020, 162, 103710. [CrossRef]

30. Andrews, J.E.; Samways, G.; Shimmield, G.B. Historical storage budgets of organic carbon, nutrient and contaminant elements in saltmarsh sediments: Biogeochemical context for managed realignment, Humber Estuary, UK. Sci. Total Environ. 2008, 405, 1-13. [CrossRef] [PubMed]

31. Heiri, O.; Lotter, A.F.; Lemcke, G. Loss on ignition as a method for estimating organic and carbonate content in sediments: Reproducibility and comparability of results. J. Paleolimnol. 2001, 25, 101-110. [CrossRef]

32. McArdle, B.H.; Anderson, M.J. Fitting multivariate models to community data: A comment on distance-based redundancy analysis. Ecology 2001, 82, 290-297. [CrossRef]

33. Legendre, P.; Andersson, M.J. Distance-Based Redundancy Analysis: Testing Multispecies Responses in Multifactorial Ecological Experiments. Ecol. Monogr. 1999, 69, 1-24. [CrossRef]

34. Shannon, C.E.; Weaver, W. The Mathematical Theory of Communication; University of Illinois Press: Urbana, IL, USA, 1949.

35. Pielou, E.C. An Introduction to Mathematical Ecology; Wiley-Interscience a Division of John Wiley \& Sons: New York, NY, USA; London, UK; Sydney, Australia; Toronto, ON, Canada, 1969.

36. Clarke, K.R.; Warwick, R.M. Change in Marine Communities: An Approach to Statistical Analysis and Interpretation, 2nd ed.; PML: Plymouth, UK, 2001. 
37. Clarke, K.R.; Gorley, R.N. PRIMER v.6: User Manual/Tutorial; Plymouth: Plymouth, UK, 2006.

38. Qinghong, L. A model for species diversity monitoring at community level and its applications. Environ. Monit. Assess. 1995, 34, 271-287. [CrossRef]

39. Desroy, N.; Warembourg, C.; Dewarumez, J.M.; Dauvin, J.C. Macrobenthic resources of the shallow soft-bottom sediments in the eastern English Channel and southern North Sea. ICES J. Mar. Sci. 2002, 60, 120-131. [CrossRef]

40. Ysebaert, T.; Herman, P.M.J. Spatial and temporal variation in benthic macrofauna and relationships with environmental variables in an estuarine, intertidal soft-sediment environment. Mar. Ecol. Prog. Ser. 2002, 244, 105-124. [CrossRef]

41. Ellis, J.T.; Ysebaert, T.; Hume, A.; Norkko, T.; Bult, P.; Herman, S.; Thrush, S.; Oldman, J. Predicting macrofaunal species distributions in estuarine gradients using logistic regression and classification systems. Mar. Ecol. Prog. Ser. 2006, 316, 69-83. [CrossRef]

42. Fraschetti, S.; Claudet, J.; Grorud-Colvert, K. Management transitioning from Single-Sector management to Ecosystem-Based management: What can marine protected areas offer? In Marine Protected Areas: A Multidisciplinary Approach; Claudet, J., Ed.; Cambridge University Press: Cambridge, UK, 2011; pp. 11-34. [CrossRef]

43. Van Hoey, G.; Degraer, S.; Vinx, M. Macrobenthic community structure of soft-bottom sediments at the Belgian Continental Shelf. Estuar. Coast. Shelf Sci. 2004, 59, 599-613. [CrossRef]

44. Bolam, S.G.; Eggleton, J.; Smith, R.; Mason, C.; Vanstaen, K.; Rees, H.L. Spatial distribution of macrofaunal assemblages along the English Channel. J. Mar. Biolog. Assoc. 2008, 88, 675-687. [CrossRef]

45. Shumchenia, E.J.; King, J.W. Comparison of methods for integrating biological and physical data for marine habitat mapping and classification. Cont. Shelf Res. 2010, 30, 1717-1729. [CrossRef]

46. Touhami, F.; Bazairi, H.; Badaoui, B.; Bouarour, O.; Benhoussa, A. Merja Zerga lagoon: Study of the functional structure and bioassessment of the ecological quality of benthic communities. J. Mater. Environ. Sci. 2017, 8, 4591-4599. [CrossRef]

47. Kjerfve, B. Comparative oceanography of coastal lagoons. In Estuarine Variability; Wolfe, D.A., Ed.; Academic Press: New York, NY, USA, 1986; pp. 63-81.

48. Pouzet, P.; Maanan, M. Climatological influences on major storm events during the last millennium along the Atlantic coast of France. Sci. Rep. 2020, 10, 12059. [CrossRef] [PubMed]

49. Rhoads, D.C.; Boyer, L.F. The effects of marine benthos on physical properties of sediments. A successional perspective. In Animal-Sediment Relations: The Biogenic Alteration of Sediments; McCall, P.L., Tevesz, M.J.S., Eds.; Plenum Publishing: New York, NY, USA, 1982; pp. 3-52.

50. Snelgrove, P.V.R.; Butman, C.A. Animal-Sediment relationship revisited: Cause versus effect. Oceanogr. Mar. Biol. Annu. Rev. 1994, 32, 111-117.

51. Kröncke, I. Structure and function of macrofaunal communities influences by hydrodynamically controlled food availability in the Wadden Sea, the open North Sea, and the Deep-sea. A synopsis. Senckenb. Marit. 2006, 36, 123-164. [CrossRef]

52. Kröncke, I.; Bergfeld, C. North Sea Benthos: A review. Senckenb. Marit. 2003, 33, 205-268. [CrossRef]

53. Pearson, T.H.; Rosenberg, R. Macrobenthic succession in relation to organic enrichment and pollution of the marine environment. Oceanogr. Mar. Biol. Annu. Rev. 1978, 16, 229-311.

54. Chaouti, A.; Azirar, A.; Bayed, A. Macrofaunal spatial distribution and community structure in a lagoon without a river discharge (the Oualidia lagoon, NW Morocco). Mar. Ecol. 2019, 40, e12557. [CrossRef]

55. Kersten, M.; Piersma, T.; Smit, C.; Zegers, P. Wader Migration along the Atlantic Coast of Morocco, March 1981; Report Netherlands Morocco Expedition 1981. RIN Report 83/20, R.I.N., Texel. 1983. Available online: https:/ /library.wur.nl/WebQuery/wurpubs/ fulltext/383011 (accessed on 23 April 2021).

56. Rharbi, N. Essai D'élevage de la Palourde Ruditapes decussatus (L.) Dans la Lagune de Moulay Bousselham (Côte Atlantique Marocaine). Ph.D. Thesis, Université Mohammed V, Rabat, Morocco, 1990.

57. Joulami, L. Ecologie Alimentaire Des Limicoles Dans la Lagune de Sidi Moussa (El Jadida). Master's Thesis, Université Hassan II, Casablanca, Morocco, 2008.

58. Joulami, L. Interactions Entre Les Conditions Ecologiques, le Benthos et Les Communautés des Limicoles Dans un Ecosystème Côtier du Nord-Ouest de L'Afrique (Lagune de Sidi Moussa. Maroc). Ph.D. Thesis, Université Hassan II, Casablanca, Morocco, 2013.

59. Chbicheb, A. Organisation Biogéologique D’un Bassin Paralique: La lagune de Oualidia (Côte Atlantique Marocaine). Ph.D. Thesis, Université de Nantes, Nantes, France, 1996.

60. Lefrere, L. Contribution à l'Etude de Deux Lagunes Atlantiques Marocaines, Khnifiss et Oualidia: Faune Malacologique, Biologie de Trois Mollusques Bivalves et Contamination Métallique. Ph.D. Thesis, Université Ibn Zohr, Agadir, Morocco, 2012.

61. El Asri, F.; Martin, D.; Errhif, A.; Tamsouri, M.N.; Maanan, M.; Zidane, H. Community Structure and Spatial Patterns of Soft-Bottom Macrozoobenthos in Oualidia Lagoon, Moroccan Atlantic. Thalassas 2020, 37, 1-11. [CrossRef]

62. Bayed, A.; El Agbani, M.A.; Fekhaoui, M.; Schouten, J.R. Benthos of soft substrates in the intertidal zone of the Khnifiss lagoon. In The Khnifiss Lagoon and Its Surrounding Environment (Province of Laayoune, Morocco); Dakki, M., Ligny, W., Eds.; Travaux de L'institut Scientifique Mém, Hors-Série, Institut Scientifique: Rabat, Morocco, 1988; pp. 71-80.

63. Afli, A.; Chakroun, R.; Ayari, R.; Aissa, P. Seasonal and spatial variability of the community and trophic structure of the benthic macrofauna within Tunisian lagoonal and marine coastal areas (Southwestern Mediterranean). J. Coast. Res. 2009, 25, 1198-1209. [CrossRef] 
64. Magni, P.; Draredja, B.; Melouah, K.; Como, S. Patterns of seasonal variation in lagoonal macrozoobenthic assemblages (Mellah lagoon, Algeria). Mar. Environ. Res. 2015, 109, 168-176. [CrossRef]

65. Como, S.; Magni, P. Temporal changes of a macrobenthic assemblage in harsh lagoon sediments. Estuar. Coast. Shelf Sci. 2009, 83, 638-646. [CrossRef]

66. Magni, P.; Micheletti, S.; Casu, D.; Floris, A.; De Falco, G.; Castelli, A. Macrofaunal community structure and distribution in a muddy coastal lagoon. Chem. Ecol. 2004, 20, 397-407. [CrossRef]

67. Morelos-Villegas, A.; Condal, A.R.; Ardisson, P.L. Spatial heterogeneity and seasonal structure of physical factors and benthic species in a tropical coastal lagoon, Celestun, Yucatán Peninsula. Reg. Stud. Mar. Sci. 2018, 22, 136-146. [CrossRef]

68. Uwadiae, R.E. An inventory of the benthic macrofauna of Epe lagoon, south-west Nigeria. IJSRD 2010, 12, 161-171.

69. Marzano, C.N.; Liaci, L.S.; Fianchini, A.; Gravina, F.; Mercurio, M.; Corriero, G. Distribution, persistence and change in the macrobenthos of the Lagoon of Lesina (Apulia, Southern Adriatic Sea). Oceanol. Acta 2003, 26, 57-66. [CrossRef]

70. Menioui, M.; Zine, N.E. Etat des Connaissances sur la Biodiversité (Faune Benthique) D’une Lagune Méditerranéenne: Lagune de Nador; Rapp. Comm. Int. Mer Médit.; CIESM: Monaco, 1995; pp. 34-83.

71. Gamito, S. Benthic Ecology of Semi-Natural Coastal Lagoons, in the Ria Formosa (Southern Portugal), Exposed to Different Water Renewal Regimes. Hydrobiologia 2006, 555, 75-87. [CrossRef]

72. Sfriso, A.; Birkemeyer, T.; Ghetti, P.F. Benthic macrofauna changes in areas of Venice lagoon populated by seagrasses or seaweeds. Mar. Environ. Res. 2001, 52, 323-349. [CrossRef]

73. Brown, A.C. The Diversity and Density of Macrobenthic Fauna in the Western Part of the Lagos lagoon, Lagos, South-West, Nigeria. Ph.D. Thesis, University of Lagos, Lagos, Nigeria, 2000.

74. Solis-Weiss, V.; Aleffi, F.; Bettoso, N.; Rossin, P.; Orel, G.; Umani, S.F. Effects of industrial and urban pollution on the benthic macrofauna in the Bay of Muggia (industrial port of Trieste, Italy). Sci. Total Environ. 2004, 328, 247-263. [CrossRef]

75. Bettoso, N.; Aleffi, I.F.; Faresi, L.; Rossin, P.; Mattassi, G.; Crivellaro, P. Evaluation on the ecological status of the macrozoobenthic communities in the Marano and Grado Lagoon (northern Adriatic Sea). Ann. Ser. Hist. Nat. 2010, 20, $193-206$.

76. Marchini, A.; Gauzer, K.; Occhipinti-Ambrogi, A. Spatial and temporal variability of hard-bottom macrofauna in a disturbed coastal lagoon (Sacca di Goro, Po River Delta, northwestern Adriatic Sea). Mar. Pollut. Bull. 2004, 48, 1084-1095. [CrossRef]

77. Bazairi, H.; Bayed, A.; Hily, C. Structure et bioévaluation de l'état écologique des communautés benthiques d'un écosystème lagunaire de la côte atlantique marocaine. Comptes Rendus Biol. 2005, 328, 977-990. [CrossRef]

78. Piersma, T. Investigations of the benthic macrofauna. In Wader Migration along the Atlantic Coast of Morocco; Kersten, M., Piersma, T., Smit, C., Zegers, P., Eds.; R.I.N Report 83/20, Texel; 1981. Available online: https:/ / research.wur.nl/en/publications/wadermigration-along-the-atlantic-coast-of-morocco-march-1981-re (accessed on 23 April 2021).

79. Bachelet, G.; de Montaudouin, X.; Auby, I.; Labourg, P. Seasonal changes in macrophyte and macrozoobenthos assemblages in three coastal lagoons under varying degrees of eutrophication International Committee for Exploration of the Seas. J. Mar. Sci. 2000, 57, 1495-1506. [CrossRef]

80. Blanchet, H.; de Montaudouin, X.; Lucas, A.; Chardy, P. Heterogeneity of macrozoobenthic assemblages within a Zostera noltii seagrass bed: Diversity, abundance, biomass and structuring factors. Estuar. Coast. Shelf Sci. 2004, 61, 111-123. [CrossRef]

81. Sueur, F.; Desprez, M.; Fagoft, C.; Triplet, P. La baie de Somme: Un site Sous-Exploité par les oiseaux d'eau. Alauda 2003, 71, 49-58.

82. Khedhri, I.; Atoui, A.; Brahim, M.; Afli, A.; Aleya, L. Assessment of surface sediment dynamics and response of benthic macrofauna assemblages in Boughrara Lagoon (SW Mediterranean Sea). Ecol. Indic. 2016, 70, 77-88. [CrossRef]

83. Mills, E.L. The community concept in marine zoology with comments on continua and instability in somemarine communities: A review. J. Fish. Res. Board Can. 1969, 26, 1415-1428. [CrossRef]

84. Thorson, G. Bottom communities (sublittoral or shallowshelf). Mem. Geol. Soc. Am. 1957, 67, 461-534. [CrossRef]

85. Bazairi, H.; Bayed, A.; Hily, C.; Glémarec, M. Spatial organisation of macrozoobenthic communities as a reponse to environmental factors in a coastal lagoon of North West African Coast (Merja Zerga, Morocco). Oceanol. Acta 2003, 26, 457-471. [CrossRef]

86. Elkaim, B. Bionomie et écologie des peuplements des substrats meubles d'un estuaire atlantique marocain: L'estuaire du Bou Regreg. III-Unités indicatrices supralittorales ou en position supralittorale. Milieu 1977, 27, 27-83.

87. Cherkaoui, E.; Bayed, A.; Hily, C. Organisation spatiale des peuplements macrozoobenthiques subtidaux d'un estuaire de la côte atlantique marocaine: L'estuaire du Bou Regreg. Cah. Biol. Mar. 2003, 22, 339-352.

88. Chaouti, A.; Azirar, A.; Zourarah, B.; Bayed, A. Patterns of spatial subtidal macrobenthic community distribution in relation to abiotic conditions in a North African estuarine ecosystem (northwestern Morocco). Ann. Zool. Fenn. 2016, 53, 125-138. [CrossRef]

89. Le Bris, H.; Glémarec, M. Marine and brackish ecosystems of south Brittany (Lorient and Vilaine Bays) with particular reference to the effect of the turbidity maxima. Estuar. Coast. Shelf Sci. 1996, 42, 737-753. [CrossRef]

90. Carvalho, S.; Ravara, A.; Quintino, V.; Rodrigues, A.M. Macrobenthic community characterisation of an estuary from the western coast of Portugal (Sado estuary) prior to dredging operations. Bol. Inst. Esp. Oceanogr. 2001, 17, 179-190.

91. Sousa, R.; Dias, S.; Freitas, V.; Antunes, J.C. Subtidal macrozoobenthic asemblages along the River Minho estuarine gradient (north-west Iberian Peninsula). Aquat. Conserv. 2008, 18, 1063-1077. [CrossRef]

92. De Paz, L.; Neto, J.M.; Marques, J.C.; Laborda, A.J. Response of intertidal macrobenthic communities to long term human induced changes in the eo estuary (Asturias, Spain): Implications for environmental management. Mar. Environ. Res. 2008, 66, 288-299. [CrossRef] [PubMed] 
93. Sánchez-Moyano, J.E.; García-Asencío, I.; García-Gómez, J.C. Spatial and temporal variation of the benthic macrofauna in a grossly polluted estuary from south-western Spain. Helgol. Mar. Res. 2010, 64, 155-168. [CrossRef]

94. Herman, P.M.J.; Middelburg, J.J.; van de Koppel, J.; Heip, C.H.R. Ecology of estuarine macrobenthos. Adv. Ecol. Res. 1999, 29, 195-240. [CrossRef]

95. Cozzoli, F.; Smolders, S.; Eelkema, M.; Ysebaert, T.; Escaravage, V.; Temmerman, S.; Meire, P.; Herman, P.M.J.; Bouma, T.J. A modeling approach to assess coastal management effects on benthic habitat quality: A case study on coastal defense and navigability. Estuar. Coast. Shelf Sci. 2017, 184, 67-82. [CrossRef]

96. Quintino, V.; Rodrigues, A.M. Environment Gradients and Distribution of Macrozoobenthos in Three Portuguese Coastal Systems: Obidos, Albufeira and Alvor; Ryland, J.S., Tyler, P.A., Eds.; Reproduction, Genetics, and Distribution of Marine Organisms, Olsen \& Olsen: Fredensborg, Denmark, 1989; pp. 441-450.

97. Teske, P.R.; Wooldridge, T.H. What limits the distribution of subtidal macrobenthos in permanently open and temporarily open/closed South African estuaries? Salinity vs. sediment particle size. Estuar. Coast. Shelf Sci. 2003, 57, 225-238. [CrossRef]

98. Ysebaert, T.; Herman, P.M.J.; Meire, P.; Craeymeersch, J.; Verbeek, H.; Heip, C.H.R. Large-Scale spatial patterns in estuaries: Estuarine macrobenthic communities in the Schelde estuary, NW Europe. Estuar. Coast. Shelf Sci. 2003, 57, 335-355. [CrossRef]

99. Elliott, M.; Quintino, V. The Estuarine Quality Paradox, Environmental Homeostasis and the difficulty of detecting anthropogenic stress in naturally stressed areas. Mar. Pollut. Bull. 2007, 54, 640-645. [CrossRef] [PubMed]

100. MacKay, F.; Cyrus, D.; Russell, K.L. Macrobenthic invertebrate response to prolonged drought in South Africa's largest estuarine lake complex. Estuar. Coast. Shelf Sci. 2010, 86, 553-567. [CrossRef]

101. Fredriksen, S.; de Backer, A.; Boström, C.; Christie, H. Infauna from Zostera marina L. meadows in Norway. Differences in vegetated and unvegetated areas. Mar. Biol. Res. 2010, 6, 189-200. [CrossRef]

102. Ganthy, F.; Sottolichio, A.; Verney, R. Seasonal modification of tidal flat sediment dynamics by seagrass meadows of Zostera noltii (Bassin d'Arcachon, France). J. Mar. Syst. 2013, 109, S233-S240. [CrossRef]

103. Self, R.F.L.; Jumars, P.A. Cross-Phyletic patterns of particle selection by deposit feeders. J. Mar. Res. 1988, 46, 119-143. [CrossRef]

104. Pinedo, S.; Sardá, R.; Rey, C.; Bhaud, M. Effect of sediment particle size on recruitment of Owenia fusiformis in the Bay of Blanes (NW Mediterranean Sea): An experimental approach to explain field distribution. Mar. Ecol. Prog. Ser. 2000, 203, 205-213. [CrossRef]

105. Por, F.D. A classification of hypersaline waters, based on trophic criteria. Mar. Ecol. 1980, 1, 121-131. [CrossRef]

106. Mariani, S. Can spatial distribution of ichthyofauna describe marine influence on coastal lagoons? A central Mediterranean case study. Estuar. Coast. Shelf Sci. 2001, 52, 261-267. [CrossRef]

107. Petit, G. Introduction à l'étude écologique des étangs méditerranéens. Milieu 1953, 4, 569-604.

108. Aguesse, P. La classification des eaux poikilohalines, sa difficulté en Camargue. Nouvelle tentative de classification. Milieu 1957, 8, 341-365.

109. D'Ancona, U. The classification of brackish waters with reference to the North Adriatic lagoons. Archo Oceanogr. Lirmol. 1959, 11, 93-109.

110. McLusky, D.S. Estuarine benthic ecology: A European perspective. Aust. J. Ecol. 1999, 24, 302-311. [CrossRef]

111. Magni, P.; Como, S.; Montani, S.; Tsutsumi, H. Interlinked temporal changes in environmental conditions, chemical characteristics of sediments and macrofaunal assemblages in an estuarine intertidal sandflat (Seto Island Sea, Japan). Mar. Biol. 2006, 149, 1185-1197. [CrossRef]

112. Padedda, B.M.; Pulina, S.; Magni, P.; Sechi, N.; Lugliè, A. Phytoplankton dynamics in relation to environmental changes in a Phytoplankton-Dominated Mediterranean lagoon (Cabras Lagoon, Italy). Adv. Oceanogr. Limnol. 2012, 3, 147-169. [CrossRef] 